\title{
ANALISIS PROSEDUR PEMBERIAN KREDIT PEMILIKAN RUMAH (KPR) DALAM PENCEGAHAN KREDIT MACET PADA PT. BANK SUMSEL BABEL PUSAT
}

\author{
Oleh: Wiranti ${ }^{1}$, Zahruddin Hodsay ${ }^{2}$, Chandra Kurniawan ${ }^{3}$ \\ (UNIVERSITAS PGRI PALEMBANG) \\ wirantiwiranti98@gmail.com ${ }^{1}$, zhodsay@ gmail.com ${ }^{2}$, \\ Chandrakurniawan79@gmail.com ${ }^{3}$
}

\begin{abstract}
Abstrak-Kredit macet atau problem loan adalah kredit yang pada kegiatannya belum sesuai sasaran yang direncanakan pihak bank, kredit yang mempunyai resiko bagi pihak bank pada masa yang akan datang dalam artian luas, kredit yang terdapat kesulitan pada penyelesaiannya, dalam pengembalian pokok atau pembayaran bunga, denda atas keterlambatan pembayaran dan ongkos-ongkos bank yang membebankan pihak debitur. Analisis yang digunakan dalam penelitian ini adalah metode kualitatif. Teknik pengumpulan data yaitu wawancara (Interview), pengamatan (observasi) dan dokumentasi. Instrumen penelitian berupa dokumen-dokumen dan catatan-catatan perusahaan yaitu PT. Bank Sumsel Babel Pusat yang berhubungan dengan penelitian ini. Hasil penelitian ini menyatakan Prosedur pemberian PT. Bank Sumsel Babel Pusat sudah berjalan cukup baik dan benar secara keseluruhan tetapi masih ada permasalahan yang harus diperhatikan dan diperbaiki untuk mengantisipasi kesalahan dalam proses pemberian KPR. Faktor penyebab terjadi kegagalan dalam pengajuan KPR pada PT. Bank Sumsel Babel Pusat ada yang berasal dari pihak perusahaan (intern) dan dari pihak debitur (ekstern).
\end{abstract}

Kata kunci: Kredit Pemilikan Rumah, Kredit Macet, Bank Sumsel Babel

\begin{abstract}
Bad credit or problem loans are loans whose activities have not met the target planned by the bank, loans that have risks for the bank in the future in the broad sense, loans that have difficulties in their settlement, in return of principal or payment of interest, fines for late payment and bank fees that incur debtors. The analysis used in this study is a qualitative method. Data collection techniques used in this study were interviews (interviews), observations (observations) and documentation. Research instruments in the form of documents and company records, namely PT. Bank Babel Pusat Babel related to this research. The results of this study stated that the procedure for granting PT. Bank Babel Pusat Babel has been running quite well and overall right but there are still problems that must be considered and corrected to anticipate errors in the process of giving mortgages. Factors causing failure occurred in filing KPR at PT. Bank Babel Pusat Babel comes from the company (internal) and from the debtor (external).
\end{abstract}

Keywords: Home Ownership Loans, Bad Credit, Bank Sumsel Babel 


\section{PENDAHULUAN}

Berkembangnya pembangunan nasional, yang bertitik berat pada bidang ekonomi yang mengelola kekuatan potensi ekonomi menjadi kekuatan ekonomi rill dengan memanfaatkan sarana permodalan yang ada, sebagai sarana pendukung utama dalam pembangunan tersebut, membutuhkan penyediaan dana yang cukup besar. Peran perbankan dalam pembiayaan akan semakin besar, hal tersebut disebabkan dana yang diperlukan dalam pembangunan berasal atau dihimpun dari masyarakat melalui perbankan, yang kemudian disalurkan kembali kepada masyarakat berupa pemberian kredit guna menuju ke arah yang lebih produktif. Salah satu alternatif dalam pendanaan yang dapat digunakan adalah melalui bank. Pengertian bank seperti yang tercantum dalam pasal 1 ayat 2 Undang-Undang Nomor 10 Tahun 1998 tentang Perubahan Undang-Undang Nomor 7 Tahun 1992 tentang Perbankan menyebutkan bahwa bank adalah badan usaha yang menghimpun dana dari masyarakat dalam bentuk simpanan dan menyalurkan kepada masyarakat dalam rangka meningkatkan taraf hidup rakyat banyak.

Fungsi menghimpun dan menyalurkan dana itu berkaitan erat dengan kepentingan umum, sehingga perbankan wajib menjaga dengan baik dana yang dititipkan masyarakat tersebut. Perbankan harus dapat menyalurkan dana tersebut ke bidang-bidang yang produktif, bagi pencapaian sasaran pembangunan. Salah satu unsur pokok dalam pembangunan untuk mensejahterakan rakyat adalah terpenuhinya kebutuhan masyarakat dalam bidang papan atau perumahan. Perumahan merupakan salah satu kebutuhan yang mendasar bagi manusia, baik untuk tempat tinggal, tempat usaha, perkantoran, dan lain sebagainya. Namun demikian, belum semua anggota masyarakat dapat memiliki atau menikmati rumah yang layak, sehat, aman, dan serasi.

Berdasarkan pasal 1 ayat (1) Undang-Undang Nomor 4 Tahun 1992 tentang Perumahan dan Pemukiman, ditentukan bahwa yang dimaksud dengan rumah adalah bangunan yang berfungsi sebagai tempat tinggal dan hunian bagi pembinaan keluarga. Kebutuhan akan perumahan pada masa sekarang ini merupakan masalah nasional, terutama di daerah perkotaan, yang harus dicarikan solusinya baik oleh pemerintah bersama-sama dengan masyarakat selaku pengusaha maupun selaku konsumen perumahan itu sendiri. Oleh karena itu upaya pembangunan perumahan dan pemukiman terus ditingkatkan untuk menyediakan jumlah perumahan yang makin banyak dan dengan harga yang terjangkau terutama oleh golongan 
masyarakat yang tidak mampu membeli rumah secara tunai, maka mereka akan membeli rumah secara kredit melalui lembaga perbankan dengan mengajukan Kredit Pemilikan Rumah (KPR).

Menurut Kasmir (2015:143) prosedur pemberian (Kredit Pemilikan Rumah) adalah tahaptahap yang harus dilalui sebelum sesuatu kredit diputuskan untuk dikucurkan.tujuannya adalah unttuk mempermudah bank dalam menilai kelayakan suatu permohonan kredit, prosedur pemberian kredit dan penilaian kredit oleh dunia perbankan secara umum antar bank yang satu dengan bank yang lain tidak jauh berbeda .

Selanjutnya bahwa menurut Rivai,dkk (2013:163) prosedur pemberian (Kredit Pemilikan Rumah) meliputi ketentuan dan syarat atau yang harus dilakukan sejak nasabah mengajukan permohonan kredit sampai kredit tersebut dilunaskan oleh nasabah dan untuk jenis kredit tertentu yang mempunyai kekhususan dalam ketentuan dan prosedurnya.

Berdasarkan teori di atas dapat disimpulkan bahwa,prosedur pemberian (Kredit Pemilikan Rumah) adalah cara atau ketentuan yang harus dilalui oleh debitur selaku pemohon dan kreditur selaku pemberi dalam proses pemberian kredit. Ini bertujuan untuk mengantisipasi agar kegiatan pemberian kredit tidak melanggar batasan-batasan yang telah di tentukan dan mempermudah pihak kreditur dalam melakukan penyaluran kredit kepada calon, debitur dan juga untuk menghindari terjadinya penyelewangan serta kemacetan dalam pelunasan kredit oleh debitur.

Menurut Firdaus dan Ariyanti (2011:83), prinsip-prinsip pemberian kredit yang biasa digunakan oleh kreditur, yang biasa dikenal dengan prinsip 5C, yaitu character, sifat-sifat calon pelanggan seperti kejujuran, perilaku dan ketaatannya. Capacity, perhatian yang diberikan terhadap kemampuan calon pelanggan secara umum atau kondisi kekayaan yang dimiliki perusahaan.Capital,dilihat dari segi financial.Collateral, jaminan yang mungkin bisa disita apabila ternyata calon pelanggan benar-benar tidak bisa memenuhi kewajibannya.Condition, menunjukkan pengaruh langsung dari tren ekonomi pada umumnya terhadap perusahaan yang bersangkutan yang mungkin mempunyai kemampuan pelanggan dalam memenuhi kewajibannya.

Menurut Ismail (2011:123) kredit macet merupakan "kredit yang menunggak melampaui 270 hari atau lebih.Bank akan mengalami kerugian atas kredit macet tersebut". Menurut Rivai,dkk (2013:397) kredit macet merupakan "situasi dimana persetujuan pengembalian kredit mengalami 
risiko kegagalan,bahkan menunjukkan kepada bank akan memperoleh kerugian yang potensial". Berdasarkan teori di atas dapat disimpulkan bahwa kredit macet ialah Nasabah yang memperoleh kredit dari bank tidak seluruhnya dapat mengembalikannya dengan baik tepat pada waktu yang disepakati. Pada kenyataannya selalu ada sebagian nasabah yang karena suatu sebab tidak dapat mengembalikan kredit kepada bank yang telah meminjaminya. Akibat nasabah tidak dapat membayar lunas utangnya,maka menjadikan perjalanan kredit terhenti atau macet Faktor-faktor penyebab kredit macet menurut Taswan (2010:466 ).

a. Faktor Internal

b. Faktor Eksternal

Menurut Kasmir (2015:149) penyelamatan kredit macet dilakukan dengan cara antara lain:

a. Rescheduling

Suatu tindakan yang diambil dengan cara memperpanjang jangka waktu kredit atau jangka waktu angsuran.

b. Reconditioning

Suatu tindakan bank mengubah berbagai persyaratan yang ada seperti kapitalisasi bunga,penundaan pembayaran bunga,penurunan suku bunga,dan pembebasan suku bunga.

c. Restructring
Suatu tindakan bank kepada nasabah dengan cara menambah modal nasabah dengan pertimbangan nasabah memang membutuhkan tambahan dana dan usaha yang dibiayai memang masih layak.

d. Kombinasi

Suatu tindakan kombinasi dari ketiga jenis yang diatas seorang nasabah dapat saja diselamatkan dengan kombinasi antara Rescheduling dengan Restructuring.

e. Penyitaan jaminan

Suatu tindakan terakhir nasabah sudah tidak benar-benar tidak punya itikad baik atapun sudah tidak mampu lagi untuk membayar semua utangutangnya.

Berdasarkan uraian latar belakang di atas, fokus dalam penelitian ini adalah sebagai berikut:

(a) Analisis prosedur Pemberian Kredit Pemilikan Rumah (KPR)

(b) Pencegahan kredit macet

Sedangkan subfokus dalam penelitian ini adalah Pemberian Kredit Pemilikan Rumah (KPR) dan Laporan Kredit Macet Tahun 2018.

Berdasarkan latar belakang, maka permasalahan dapat rumuskan sebagai berikut yaitu Bagaimanakah prosedur Pemberian Kredit Pemilikan Rumah (KPR) dalam pencegahan kredit macet pada PT. Bank Sumsel Babel Pusat? 
Adapun tujuan Penelitian ini adalah untuk mengetahui prosedur Pemberian Kredit Pemilikan Rumah (KPR) dalam pencegahan kredit macet pada PT. Bank Sumsel Babel Pusat.

\section{METODOLOGI PENELITIAN}

Metode penelitian yaitu deskriptif kualitatif. Data dan Sumber Data yaitu Data Primer dan Data Sekunder. Metode pengumpulan data yang digunakan dalam penelitian ini adalah wawancara, observasi, dan dokumentasi. Wawancara dilakukan untuk mengetahui apa saja produk, berhubungan yang dianalisis dan bagaimana prosedur Bank Sumsel Babel tersebut dalam pengajuan KPR. Observasi dilakukan untuk melihat kondisi dan situasi apa yang menyebabkan kredit macet. Sedangkan metode dokumentasi yang digunakan untuk pengambilan data atau catatan yang ada di objek penelitian dan melengkapi data yang didapat dari perusahaan dengan melihat atau mempelajari buku-buku yang berisi informasi yang ada kaitannya dengan masalah yang dibahas.

\section{HASIL DAN PEMBAHASAN}

Sebagian besar kegiatan perekonomian masyarakat membutuhkan kredit, melalui pemberian kredit nasabah melakukan pembayaran melalui rekening makin bertambah sehingga tujuan dari pemberian kredit selain untuk mendapatkan hasil yang optimal dari pemberian kredit, juga untuk meningkatkan pendapatan bank karena dana dalam bank akan bertambah dengan sendirinya. Untuk memenuhi kebutuhan masyarakat dalam bidang papan, PT. Bank Sumsel Babel Pusat mengeluarkan produk kredit perumahan yaitu KPR Griya Sejahtera. KPR Griya Sejahtera adalah kredit rumah, ruko, rukan, rusunami, apartemen, condotel maksimal kredit 5 milyar, masyarakat diharapkan dapat memiliki rumah dengan angsuran rendah sehingga tidak memberatkan masyarakat dan realisasi kredit yang cepat. Angsuran yang tidak memberatkan tersebut diberikan pada masyarakat dikarenakan PT. Bank Sumsel Babel.

Prosedur Pemberian Kredit Pemilikan Rumah (KPR) pada PT. Bank Sumsel Babel Pusat yaitu menurut teori Suyatno (2011:62) yaitu;

1. Pengajuan Permohonan Kredit Kredit pemilikan rumah (KPR) Kredit Griya Sejahtera adalah fasilitas kredit perumahan yang diberikan oleh PT. Bank Sumsel Babel kepada masyarakat yang mempunyai penghasilan untuk melakukan kredit rumah.

2. Penyeleksian Pemberian Kredit Kredit macet atau problem loan adalah kredit yang mengalami kesulitan pelunasan akibat 
adanya faktor-faktor atau unsur kesengajaan atau kondisi di luar kemampuan debitur. Kredit macet yaitu kredit yang pengembalian pokok pinjaman dan pembayaran bunganya terdapat tunggakan telah melampaui 270 hari. Kredit macet merupakan kondisi dimana pihak bank merasa dirugikan. Pengalaman kredit macet akhir-akhir ini telah mengacu kalangan perbankan untuk lebih berhati-hati dalam mengatur alokasi dana kredit. Penyeleksian konsumen yang mencakup teori 5C, BI dan penghasilan konsumen (character, capacity, capital, collateral, condition, personality, purpose, prospect, payment dan kebenaran income). Character dari sifatsifat Nasabah seperti kejujuran, perilaku dan ketaatanya dalam melunasi pembayaran kredit. Capacity atau kemampuan kinerja calon debitur dalam pekerjaan yang dilakukanya beserta latar belakang pendidikanya. Capital atau modal dari segi financial calon debitur secara umum. Collecteral merupakan jaminan yang bisa disita apabila ternyata calon debitur benar-benar tidak bisa memenuhi kewajibanya. Condition menunjukan pengaruh kondisi ekonomi pada umumnya terhadap kemampuan debitur dalam memenuhi kewajibanya. Personality atau kepribadian calon debitur merupakan segi yang subjektif namun menjadi suatu yang penting dalam penentuan pemberian KPR. Purpose menyangkut tujuan penggunaan kredit tersebut tidak mengandung unsur spekulatif. Payment yaitu cara pembayaranya misalnya mengenai aliran dana. Income atau penghasilan calon debitur apakah mampu membayar angsuran tersebut untuk jangka panjang. BI yaitu sejarah perkredit debitur apabila selama perjalanan kredit, debitur penah melakukan kredit tempat lain atau sejenisnya dan ternyata sejarahnya buruk maka pengajuan KPRnya akan langsung ditolak oleh pihak Analis Kredit tanpa melakukan proses selanjutnya. Adapun apabila debitur sejarahnya mengalamin penunggakan yang tidak terlalu berat maka pihak analis memberikanan prasyarat kepada debitur agar debitur bisa melanjutkan proses selanjutnya. Sebaliknya apabila debitur tidak ada masalah dengan BI nya maka debitur tersebut bisa langsung ketahap proses selanjutnya.

3. Keputusan Atas Permohonan Kredit 
Berkas-berkas mengenai calon debitur dari tahap awal hingga DUP atau OTS diserahkan pada komisi pemutus kredit untuk di setujui. Dalam tahap ini dilakukan OTS 2 bagi calon debitur yang berpenghasilan tetap apakah memenuhi kriteria atau tidak, apabila tidak memenuhi kriteria maka dibuat surat penolakan, jika memenuhi kriteria maka dibuat SP3K (Surat Penegasan Persetujuan Penyediaan Kredit).

4. Pelunasan Pemberian Kredit

Pelunasan pemberian kredit merupakan dipenuhinya semua kewajiban hutang pelanggan terhadap perusahaan yang berkaitan atau pelunasan pemberian kredit yang dilakukan pihak debitur, Debitur telah diwajibkan melakukan pembayaran bulan sampai tahun pelunasan dapat dilakukan melalui rekening bank tersebut di setiap bulannya langsung.

Berikut ini perkembangan Kredit Griya Sejahtera PT. Bank Sumsel Babel Pusat Tahun 20172018 :
Tabel 1. Griya Sejahtera PT. Bank Sumsel Babel Pusat Tahun 2017-2018 (Dalam Jutaan Rupiah)

\begin{tabular}{|c|c|c|}
\hline Tahun & $\begin{array}{c}\text { Jumlah } \\
\text { (Rp) }\end{array}$ & $\begin{array}{c}\text { Naik/Turun } \\
(\boldsymbol{\%})\end{array}$ \\
\hline 2017 & 303.001 & \multirow{2}{*}{23,89} \\
\hline 2018 & 375.389 & \\
\cline { 1 - 2 }
\end{tabular}

Sumber: PT. Bank Sumsel Babel Pusat

Prosedur Pemberian Kredit Pemilikan Rumah (KPR) pada PT. Bank Sumsel Babel Pusat terdiri dari :

1. Prosedur pemberian Kredit Pemilikan Rumah (KPR) pada PT. Bank Sumsel Babel Pusat Unit Pemasaran adalah tahap pengajuan permohonan KPR. Tahap ini mencakup pengajuan pemberian KPR, menyiapkan berkas-berkas seperti fotocopy KTP, fotocopy KK , fotocopy NPWP, fotocopy surat nikah, pasfoto suami istri, fotocopy tabungan 3 bulan terakhir dan info BI dan mengisi formulir aplikasi pemohonan KPR.

2. Penyeleksian konsumen yang mencakup teori 5C, BI dan penghasilan konsumen (character, capacity, capital, collateral, condition, personality, purpose, prospect, payment dan kebenaran income). Character dari sifat-sifat Nasabah seperti kejujuran, perilaku dan ketaatanya dalam melunasi pembayaran kredit. Capacity atau 
kemampuan kinerja calon debitur dalam pekerjaan yang dilakukanya beserta latar belakang pendidikanya. Capital atau modal dari segi financial calon debitur secara umum. Collecteral merupakan jaminan yang bisa disita apabila ternyata calon debitur benar-benar tidak bisa memenuhi kewajibanya. Condition menunjukan pengaruh kondisi ekonomi pada umumnya terhadap kemampuan debitur dalam memenuhi kewajibanya. Personality atau kepribadian calon debitur merupakan segi yang subjektif namun menjadi suatu yang penting dalam penentuan pemberian KPR. Purpose menyangkut tujuan penggunaan kredit tersebut tidak mengandung unsur spekulatif. Payment yaitu cara pembayaranya misalnya mengenai aliran dana. Income atau penghasilan calon debitur apakah mampu membayar angsuran tersebut untuk jangka panjang. BI yaitu sejarah perkredit debitur apabila selama perjalanan kredit, debitur penah melakukan kredit tempat lain atau sejenisnya dan ternyata sejarahnya buruk maka pengajuan KPRnya akan langsung ditolak oleh pihak Analis Kredit tanpa melakukan proses selanjutnya. Adapun apabila debitur sejarahnya mengalamin penunggakan yang tidak terlalu berat maka pihak analis memberikanan prasyarat kepada debitur agar debitur bisa melanjutkan proses selanjutnya. Sebaliknya apabila debitur tidak ada masalah dengan BI nya maka debitur tersebut bisa langsung ketahap proses selanjutnya..

3. Keputusan atas permohonan KPR yang dilakukan oleh Unit Pemasaran PT. Bank Sumsel Babel Pusat berdasarkan wewenangnya dan berhak mengambil keputusan menolak atau menyetujui permohonan KPR. Tahap terakhir yaitu melakukan akad Kredit di depan Notaris, Pihak Debitur, Pihak Bank dan pihak Penjual atau Developer.

4. Pelunasan pemberian kredit yang dilakukan pihak debitur, Debitur telah diwajibkan melakukan pembayaran bulan sampai tahun pelunasan dapat dilakukan melalui rekening bank tersebut di setiap bulannya langsung.

Dalam prosedur pemberian KPR Unit Pemasaran PT. Bank Sumsel Babel Pusat sudah berjalan cukup baik dan benar secara keseluruhan tetapi masih ada permasalahan yang harus diperhatikan dan diperbaiki untuk mengantisipasi kesalahan dalam proses pemberian KPR. Pada penyeleksian calon debitur terdapat masalah yang pertama dalam character debitur tidak bisa 
mentaati kesepakatan pembayaran kewajibannya yang telah diberikan dengan asumsi debitur dalam kesulitan keuangan karena usaha yang mereka jalankan juga mengalami masalah sehingga debitur menunggak pembayaran pada bulan yang telah disepakati, akibatnya terjadi penumpukan piutang karena keterlambatan debitur melakukan pembayaran. Hal ini dapat disimpulkan bahwa analisis kredit hanya melihat data seperti debitur belum memiliki rumah dan belum pernah menerima subsidi pemerintah untuk pemilikan rumah yang dikeluarkan dari kantor camat tempat tinggal debitur, memiliki NPWP dan SPT tahunan $\mathrm{PPH}$ orang pribadi sesuai perundang-undangan yang berlaku dan slip gaji sehingga analisis kredit tidak melihat secara detail fortofolio segmen kredit yang akan diberikan kepada debitur. Sebaiknya dalam masalah ini perusahaan harus memberikan surat peringatan kepada debitur dengan meminta penjelasan bagaimana pembayaran kredit yang telah diberikan untuk selanjutnya. Permasalah yang kedua dalam hal collateral debitur tidak bisa membayar atau melunasi kewajibannya tetapi perusahaan belum mau menyita jaminan yang dijaminkan pada saat pengajuan permohonan KPR dengan asumsi perusahaan masih memberikan waktu tenggang atau kompensasi untuk membayar atau melunasi kewajibanya pada bulan berikutnya sesuai dengan perjanjian yang telah disepakati sebelum KPR diberikan, akibatnya debitur menunggak untuk membayar atau melunasi kewajibanya pada saat jatuh tempo. Perusahaan harus bersikap tegas kepada debitur dalam pembayaran kewajibannya dan perusahaan bisa menyita jaminan yang dijaminkan apabila debitur tidak bisa melunasinya atau membayar kewajibannya tersebut dalam kurun waktu tertentu. Masalah yang terakhir Condition di saat keadaan krisis ekonomi debitur juga bisa terkena dampak dari krisis tersebut sehingga mempengaruhi kondisi ekonomi debitur, akbitnya pihak kreditur juga terkena dampak dari krisis tersebut karena debitur yang belum bisa membayar kewajibannya. Sebaiknya pihak kreditur harus bisa lebih baik dalam membaca peluang dan keadaan kemampuan pihak debitur sebelum memberikan KPR kepada calon debitur untuk menghindari masalah tersebut.

Kredit Griya Sejahtera (KGS) PT. Bank Sumsel Babel pada tahun 2018 sebesar Rp.375.389 juta meningkat $23,89 \%$ dibandingkan tahun 2017. Faktor utama peningkatan tersebut disebabkan oleh PT. Bank Sumsel Babel ikut serta dalam penyaluran KPR program pemerintah dan meningkatnya kerjasama dengan developer perumahan di daerah 
Sumatera Selatan dan Bangka Belitung. Rasio Non Performing Loan (NPL) Gross menunjukkan bahwa perbandingan antara kredit yang tidak dikembalikan lagi oleh debitur (kredit macet) atau dikembalikan tapi tersendat-sendat dengan total kredit yang disalurkan oleh bank ke masyarakat.Timbulnya masalah ini diduga karena kurangnya analisis kredit melakukan crosscheck data secara detail hanya melihat data (Character) oleh karyawan Bank dalam menganalisis permohonan kredit

Faktor penyebab terjadi kegagalan dalam pengajuan KPR pada PT. Bank Sumsel Babel Pusat ada yang berasal dari pihak perusahaan dan dari pihak debitur. Dari pihak perusahaan (intern),ketidak kejujuran debitur, keterbatasan penghasilan debitur (Condition) dan nilai jaminannya tidak memenuhi ketentuan yang berlaku pada prosedur perusahaan(Collateral). Dari pihak debitur (ekstern) lebih disebabkan adanya debitur yang tidak sungguhsungguh dalam pengajuan permohonan KPR yang terbukti dengan prasyarat yang tidak dilengkapi, terdapat debitur yang melarikan diri, mampu membayar tapi tidak mau melunasi kewajiban(Character).

Hasil penelitian ini sesuai dengan penelitian yang dilakukan Fadli Alanshari (2015) yang menyatakan mekanisme KPR pada
PT. Bank Sumsel Babel mulai dari mengajukan permohonan kredit, vertifikasi, wawancara, analisa, persetujuan, akad, dan realisasi bagi masyarakat cukup jelas dan memudahkan dalam mendapatkan kredit pemilikan rumahnya dengan syarat dan ketentuan yang mudah di pahami.

\section{SIMPULAN}

Berdasarkan hasil yang diperoleh dari analisa dan pembahasan dalam bab sebelumnya, maka kesimpulan yang dapat diambil untuk menjawab rumusan permasalah dari penelitian tentang analisa prosedur pemberian KPR PT. Bank Sumsel Babel Pusat adalah sebagai berikut :

a. Prosedur pemberian PT. Bank Sumsel Babel Pusat sudah berjalan cukup baik dan benar secara keseluruhan tetapi masih ada permasalahan yang harus diperhatikan dan diperbaiki untuk mengantisipasi kesalahan dalam proses pemberian KPR. Dari pihak perusahaan (intern) tersebut lebih disebabkan keterbatasan penghasilan debitur (Condition) dan nilai jaminannya tidak memenuhi ketentuan yang berlaku pada prosedur perusahaan (Collateral).

b. Dari pihak debitur (ekstern) lebih disebabkan adanya debitur yang tidak sungguh-sungguh dalam pengajuan permohonan 
KPR yang terbukti dengan persyaratan yang tidak dilengkapi, terdapat debitur yang melarikan diri, mampu membayar tapi tidak mau melunasi kewajiban(Character).

c. Pada tahap penyeleksiaan PT.Bank Sumsel Babel Pusat yang dilakukan oleh analis kredit kurangnya melakukan crosscheck data secara detail (Character) yang menyebabkan kredit macet setiap tahunnya bertambah.

\section{SARAN}

Berdasarkan penelitian yang telah dilakukan, maka penulis dapat memberikan beberapa saran kepada PT. Bank Sumsel Babel Pusat, yaitu: a. Pada pemberian KPR seharusnya dilakukan pemeriksaan secara mendadak kepada karyawan agar karyawan tidak melakukan kecurangan dan karyawan dapat melakukan pekerjaannya sesuai dengan tugas dan tanggung jawabnya dengan baik.

b. Prosedur pemberian KPR yang ada pada PT. Bank Sumsel Babel Pusat diharapkan dapat lebih ditingkatkan dalam berbagai hal agar mempermudah masyarakat untuk mendapatkan pembiayaan rumah dengan bunga yang rendah dan melakukan kerjasama dengan berbagai developer perusahaan di berbagai wilayah Kota Palembang.

c. Bagi peneliti selanjutnya dapat dijadikan salah satu bahan referensi bagi pihak yang ingin melakukan kajian lebih lanjut dengan cara melakukan perbandingan mengenai prosedur pemberian Kredit Pemilikan Rumah (KPR) dalam pencegahan kredit macet dengan bank lainnya.

\section{DAFTAR PUSTAKA}

Fadli Alanshari. 2015. Prosedur pemberian kredit KPR pada PT. Bank Tabungan Negara (Persero) Tbk Cabang Pembantu Bukittinggi. Jurnal Akademi Keuangan dan Perbankan.

Firdaus, Rachmat dan Maya, Ariyanti. 2011. Manajemen Perkreditan Bank Umum: Teori, Masalah, Kebijakan dan Aplikasi Lengkap dengan Analisis Kredit. Alfabeta : Bandung.

Halim, dkk. 2009. Sistem Pengendalian Manajemen. Yogyakarta:Penerbit Sekolah Tinggi Ilmu Manajemen.

Hibatullah, Fauzan Takalamingan. 2018. Analisis penerapan sistem dan prosedur pemberian kredit Pemilikan rumah (KPR) subsidi pada Bank Tabungan Negara Cabang Manado. Jurnal Riset Akuntansi Going Concern 13 (4), 2018, 830-840.

Informasi dari Bank Indonesia www.bankindonesia.com. 
Ismail. 2011. Manajemen Perbankan. Jakarta:Penerbit Prenada Media.

Ismail dan Prawironegoro. 2009. Sistem Pengendalian

Manajemen. Jakarta: Penerbit Mitra Wacana Media.

Kasmir. 2015. Dasar-Dasar Perbankan. Jakarta:PT.Raja Grafindo Persada.

Nur Suci Atmawati. 2015. Analisis Pemberian Kredit Pemilikan Rumah (KPR) Dalam Rangka Mengurangi Non Performing Loan (Studi pada PT. Bank Central Asia Tbk. Cabang Kediri). Jurnal Administrasi Bisnis. Vol.2 No.2 Februari 2015.

Merchan dan Van Der Stade. 2014. Sistem Pengendalian Manajemen. Jakarta: Penerbit Salembat Empat.

Putri Embun Sari. 2013. Sistem Pengendalian Internal Penyaluran Kredit Pemilikan Rumah (KPR) : Studi Kasus Pada Bank BTN Cabang Depok. Jurnal Sistem Pengendalian Manajemen.

Rivai, dkk. 2013. Credit Management Handbook. Jakarta:PT.Raja Grafindo Persada.

Ryana Fitrianingsih. 2017. Penerapan Sistem Pemberian Kredit Pemilikan Rumah (KPR) Subsidi Dalam Upaya Mengantisipasi Terjadinya Tunggakan Kredit Pada PT. Bank Tabungan Negara (Persero) Tbk. SIMCI Economic. Vol.01 No.02 Tahun 2017. ISSN.BBBB,BBBB
Sudijono. 2010. Pengantar Statistik Pendidikan. Jakarta:PT.Rajagrafindo Persada.

Sugiyono. 2018. Metode Penelitian Kuantitatif, Kualitatif dan $R \&$ $D$. Alfabeta: Bandung.

Suyatno. dkk. 2018. Dasar-dasar Perkreditan. Jakarta : Gramedia PustakaUtama.

Taswan. 2010. Manajemen Perbankan.

Yogyakarta:Penerbit UPP AMP YKPN.

Trianto. 2011. Pengantar Penelitian Pendidikan Bagi Pengembangan dan Profesi Pendidikan Tenaga Kependidikan. Penerbit Kencana Prenada Media Group: Jakarta.

Wulan Angka Sari. 2016. Analisis sistem dan prosedur pemberian kredit kepemilikan rumah (KPR) BTN bersubsidi dalam usaha mendukung pengendalian Manajemen kredit (Studi Pada PT. Bank Tabungan Negara (Persero) Tbk. Kantor Cabang Kediri). Jurnal Administrasi Bisnis (JAB). Vol.41 No.1 Desember 2016. 